\title{
Bronzino's Portrait of Guidobaldo II della Rovere
}

\author{
KONRAD EISENBICHLER
}

\section{G}

Suidobaldo's great-great-uncle, Federigo da Montefeltro, had sat for a portrait by Pedro Berruguete (1477, Palazzo Ducale, Urbino). In this very well known work (fig. 1), careful attention was given to the objects of rank and prestige which Federigo possessed and treasured: the ermine-lined crimson ducal mantle worn over the coat of armour (the ermine lining had been granted to him in 1474 by pope Sixtus IV and had been conferred upon him by the cardinals Gonzaga and Zeno at an elaborate ceremony in Rome); the golden chain of the Order of the Ermine conferred upon him by the king of Naples: the pearl-encrusted ducal tiara of Urbino, a gift of Usun Hasan, the Shah of Persia (1474); the Order of the Garter recently received from king Edward IV of England (1474) and proudly displayed on the outstretched left leg; the folio-sized book with the coat of arms of Urbino in his hands; and, last but not least, his young son and heir Guidobaldo I (who was to be the last of the Montefeltro) in pearl-encrusted robes and holding the ducal sceptre in his right hand. The portrait is tantamount to a statement of power, prestige, wealth, scholarly interests, and, ironically, a secure male lineage by which the condottiere duke wished to be remembered.

In the case of Bronzino's portrait of Guidobaldo II della Rovere, ${ }^{1}$ painted between April 1531 and April 1532, ${ }^{2}$ some of the same concerns are exhibited (fig. 2). The eighteen year-old son of the new line of dukes of Urbino (through Francesco Maria della Rovere and Eleonora Gonzaga) is seen in an elegant dark green and gold Milanese suit of armour. In his life of Pontormo, Giorgio Vasari recalls that Bronzino's return to Florence had been delayed in Pesaro because he was waiting for the arrival of Guidobaldo's new Milanese suit, which the duke had insisted he be portrayed wearing. ${ }^{3}$ We can infer, from Vasari's incidental statement, the importance Guidobaldo attached to his portrait and to this image of himself. Such care on Guidobaldo's part invites us to consider more closely the compositional elements in the portrait.

Compared with Federigo's portrait, Guidobaldo’s enjoys a clearer, 


\section{2 / Renaissance and Reformation}

simpler compositional frame. The variety of objects and the crowded canvas of Federigo's portrait give way to a few, strategically placed elements which serve to underline and emphasize the statement Guidobaldo's portrait is making. The deep green hues of the all-important suit of armour fade into the green curtain which forms the backdrop; the gold decorative pattern of the armour seems to rise from this deep green background to create lively flashes of light in an otherwise sedate composition. Guidobaldo's face, half lit and half in shade, framed by his hair, full beard, and mustache which blend into the darkness of the curtain, is reduced to a third its size; because of the lighting and the fact that it suffers no competition from other objects, the face, dominating as it does the otherwise empty upper section of the portrait, attracts the viewer's attention. This attention, however, is immediately drawn down, along the pyramid construction of the outstretched arms, from the subject's half-lit face into the lower level of the painting, where the much whiter, much bigger, and fully-lit head of Guidobaldo's mastiff attracts the viewer's gaze. At this point the observant viewer cannot help but run his eyes along this lower plane, along the tricolour combination of the mastiff's white head, the protruding red codpiece, and the dark green helmet. All three are held in or framed, as it were, by Guidobaldo's elegant hands, whose delicate white fingers have been elongated and placed in a manneristic pose.

Pausing to consider the significance of these strategically placed objects, it would seem that the mastiff and the helmet are suggestive of the family's nobility and military power. The mastiff is reminiscent of the hunt, a courtly past-time appropriate to the nobility. The helmet (which is really only an extension of Guidobaldo's much-treasured Milanese armour), a reminder of the military power not only of the della Rovere family but of the previous line of dukes of Urbino, the Montefeltro, as well. The codpiece, erect, protruding, and sizeable, is, without a doubt, an unabashed statement of virility and masculinity. Bright red with gold embroidery, this erect codpiece does not suggest love or sexual attraction, as is the case in the later portrait by Bronzino of the young Lodovico Capponi caught in the act of gazing upon his beloved's cameo (ca 1556-59, Frick Collection, NY). The stern look with which the sitter engages the viewer's eyes, as well as the military helmet and the enormous mastiff flanking the codpiece would tend to exclude such tender sentiments. It is more likely, instead, that the pronounced codpiece is intended as a general statement of Guidobaldo's virility and, by extention, to underline the yet-unmarried eighteen-year-old youth's sexual prowess. The Greek inscription on the helmet reads "It will certainly be as I have decided," 4 a statement which, placed in the context of the three symbols of power on the lower plane of the portrait and the direct gaze of the subject that engages the viewer's eyes on the upper plane, indicates in actual words the young man's determination to be fully in control, or, in terms dear to the Italian Renaissance, 
Renaissance et Réforme / 23

FIGURE 1: Pedro Berruguete. Duke Federigo da Montefeltro with his son Guidobaldo I. Palazzo Ducale, Urbino (Alinari)

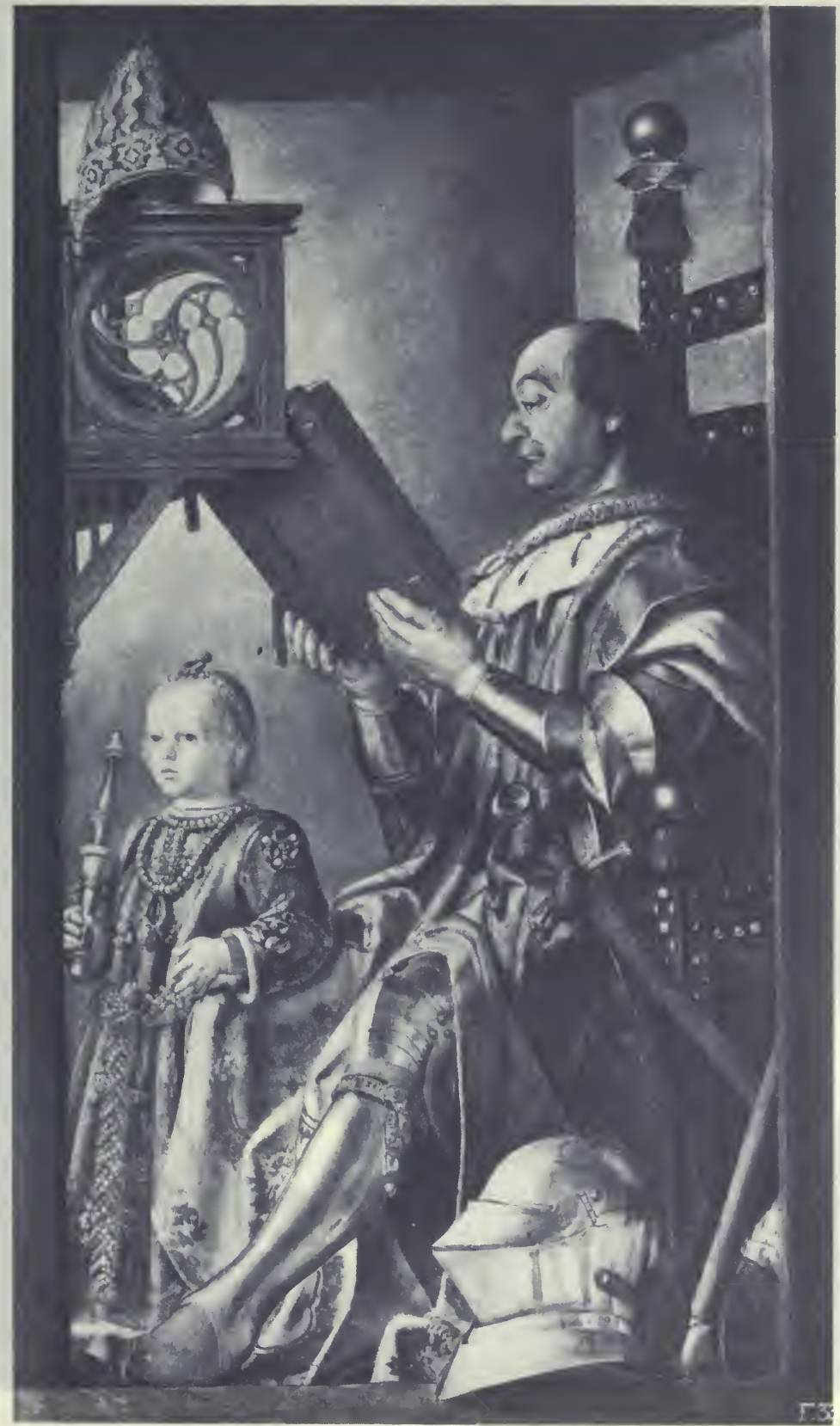


24 / Renaissance and Reformation

FIGURE 2: Agnolo Bronzino. Duke Guidobaldo II della Rovere. Pitti Gallery, Florence (Alinari)

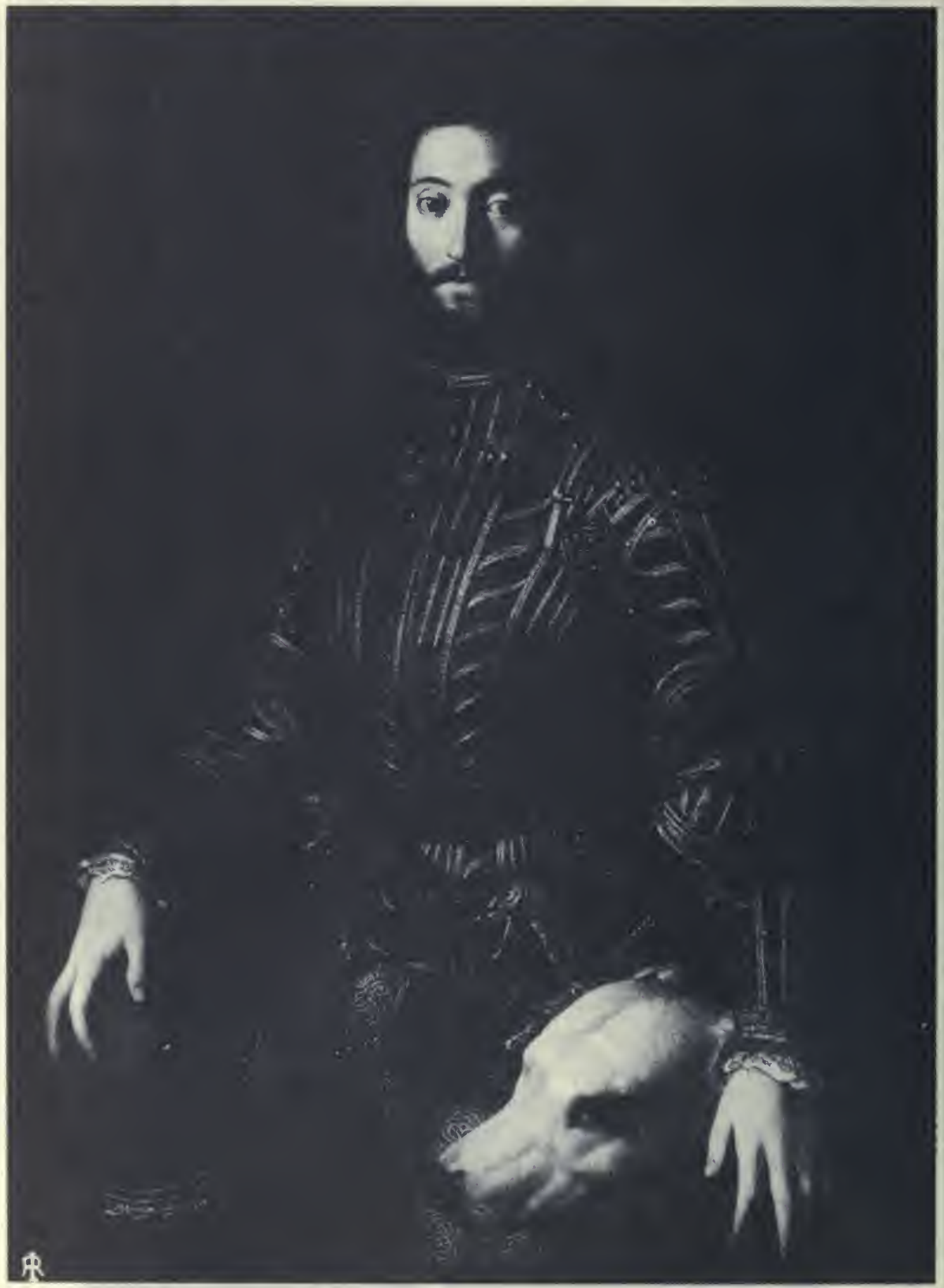


to overcome Fortuna by his own Virtù.

Having arrived at this general interpretation, it is instructive to examine the context in which the painting was commissioned and created. Craig Hugh Smyth noted that "in arrangement and effect the portrait is exceptional for Bronzino compared to his earlier portraits and to his later ones as well," and suggested that it showed "a quite new influence, that of Titian":

The spreading, unstrained pose of the figure, the line of the silhouette and its relative unobtrusiveness, the decorative placing of the somewhat delicate hands, partly obscured in soft shadows, the emphasis on the glinting ornamental accents of the armor as it catches the light, giving an effect not of precise detail in every particular but of subdued richness, the unusual weight given to color in the immediate and total effect of the picture - all this should remind one of the portraits by Titian from the twenties. ${ }^{5}$

Charles McCorquodale, in his book on Bronzino, is aware not only of the work's singularity, but also of the temporal context in which it was created:

Bronzino's Guidobaldo is certainly unlike anything [Bronzino] painted in Florence prior to this date, and the fact that Bronzino moved away from this type of portrait immediately after his return to Florence suggests that it was created under specific conditions and influences. ${ }^{6}$

Neither Smyth nor McCorquodale, however, pursue the matter further. McCorquodale's comments on the Guidobaldo serve very well as an example of how the most obvious can also be the most conscientiouly ignored element of a painting:

the figure, seen at three-quarter length, is brought to the very forefront of the pictorial space with the result that our attention is focussed on the face and hands despite the highly detailed armour. .. Bronzino uses a device which he subsequently adopted in many portraits, that of the flat surface (here the table beneath Guidobaldo's helmet) on which an arm or hand is rested. Here, as in many other portraits, this immediately suggests depth where it is otherwise barely hinted at. It also draws attention to the hands ... The Guidobaldo's avoidance of a clear outline as favoured by Pontormo and Bronzino himself to this point lends it a sumptuousness in which detail is totally subservient to the whole effect.?

Sumptuousness apart, if the viewer can notice that the table-top is there to provide depth in an otherwise 'flat' painting, how can he then ignore the codpiece which is even more effective in suggesting depth, albeit in a reverse direction, by seeming to burst out, as it were, of the otherwise flat canvas? Given the uniqueness of this portrait, which McCorquodale so rightly intuits, it becomes imperative to examine the socio-political 


\section{6 / Renaissance and Reformation}

context of the painting to see if history can help to shed light on this enigmatic detail.

In line with the perfect courtier envisioned in the pleasant Urbanese discussions of Baldassarre Castiglione, Guidobaldo della Rovere appears to us, in this portrait, as the elegant, courtly soldier-king, who literally embodies power and dominance. The young heir to the duchy may indeed have wanted to be associated with exactly these attributes. Given the unstable political situation of Italy in this period, his claim to the throne, though legitimate, was too recent to be secure. His father, duke Francesco Maria della Rovere, had received (1508) the duchy of Urbino from his paternal uncle, pope Julius II della Rovere, upon the death of his maternal uncle, Guidobaldo I da Montefeltro (the young boy in Berruguete's portrait of Federigo). The lineage was legitimate, but the process was tainted with nepotism.

Furthermore, Guidobaldo II may have wanted to underline that, unlike his namesake and previous duke of Urbino, he was a healthy, vigorous man who could and would produce an heir. History remembers Guidobaldo I from Castiglione's Book of the Courtier, where he is described as a sickly man, so crippled by gout "in all his members that he could not stand upon his feet or move." ${ }^{8}$ Castiglione continues saying:

And not even content with this, Fortune opposed him so in his every undertaking that he rarely brought to a successful issue anything he tried to do; and, although he was very wise in counsel and undaunted in spirit, it seemed that whatever he undertook always succeeded ill with him whether in arms or in anything, great or small; all of which is attested by his many calamities, which he always bore with such strength of spirit that his virtue was never overcome by Fortune; nay, despising her storms with stanch heart, he lived in sickness as if in health, and in adversity as if most fortunati, with the greatest dignity and esteemed by all. ${ }^{9}$

In fact, in The Courtier, the duke retires to his bedroom early and alone, leaving his elegant, charming, and learned wife, Elisabetta Gonzaga, to spend three nights in a row (the third one till dawn) conversing with her entourage of charming ladies and elegant gentlemen on the nature and the qualities of the perfect courtier. This debolezza on the infirm duke's part is certainly not what his younger namesake and future duke Guidobaldo II intended to project either in his portrait or by his behaviour.

The behaviour of the heir to the throne at this point in his life is also pertinent to our discussion. The year 1532, when the portrait was commissioned and painted, marks a period of strained relations between Guidobaldo II and his father Francesco Maria. Five years earlier, in 1527, Francesco Maria had betrothed Guidobaldo to Giulia Varano (15231547), heiress to the adjacent duchy of Camerino. It had been a political 
match; the heiress, a mere child of 4 , was 9 years younger than Guidobaldo. In 1532 she was only 9 years old and had not yet reached puberty. Guidobaldo, on the other hand, was a warm-blooded eighteen-year-old male, with the urges, passions, and desires natural to that age. It is not surprising, therefore, that he should fall in love and seek to fulfill his passions elsewhere. Unfortunately, like Romeo, Guidobaldo fell in love with a lady from a family politically opposed to his own; with Clarice, the daughter of Gian Giordano Orsini.

The tensions and frustrations clearly developing between father and son because of this politically unacceptable liaison can be detected in an exchange of letters dated in the fall and winter of $1532 .{ }^{10}$ Francesco Maria writes to his son voicing his strong disapproval of the youth's relationship with Clarice Orsini. First, Francesco Maria objects for reasons of noble rank and precedence; the Orsini, he points out, are socially inferior to the della Rovere and should be satisfied, as they have been in the past, with marrying della Rovere bastards, not their legitimate heirs. Second, Francesco Maria proceeds to remind his son of the political enmity between himself and some members of the Orsini family. Third, he reminds his son of the black sheep in the Orsini family; Gian Giordano himself was universally considered a madman, Francesco Maria points out, and therefore Guidobaldo should be ashamed to desire something which issued from a madman. The concerned father then changes tone, vents a sarcastic comment, "I seem to understand that you have a great fear of becoming duke of Camerino" and reminds the young man of his obligations towards his own family. The last comment in the letter is the most threatening: "and think hard about your mother, who is pregnant and can very well produce ten more."11

Guidobaldo, ignoring the obvious threat of disinheritance, responds in kind in a letter which is a curious blend of respect and arrogance (26 December 1532), praising the nobility of the Orsini and casting aspersions, in his turn, on Giulia Varano's mother, Caterina Cybo, the regent duchess of Camerino. Guidobaldo may have stepped over the bounds in this last point; Francesco Maria had strongly defended Caterina Cybo both politically and militarily for many years in anticipation of their children's marriage, and was clearly not about to forego this long-standing dynastic allegiance with her - nor was he about to undermine the advancement of both his family and his duchy.

Clearly exasperated, Francesco Maria responds with a furious letter in which, claiming to protect his own interests, he threatens to disown his son and to act with unending enmity in words and deeds towards the Orsini and anyone else who would support Guidobaldo's intentions towards Clarice. ${ }^{12}$

Shortly thereafter, in March 1533, the duchess Eleonora gave birth to a 


\section{8 / Renaissance and Reformation}

second son, Giulio (who was eventually to become a cardinal). At this point, the romance between Guidobaldo and Clarice Orsini quickly faded, and the next year, on 12 October 1534, Guidobaldo hurriedly married the 11 year-old Giulia Varano, thus adhering to his father's wishes and dynastic ambition by adding the duchy of Camerino to the della Rovere possessions. ${ }^{13}$

Returning to the portrait, painted in the year of this father-son squabble, the inscription on the helmet gains considerable importance. "It will certainly be as I have decided" may, in fact, reflect the attitude of the selfassured, wayward son, passionately caught up in a teen-age love affair. responding to a father who is telling him to forego such passion for the sake of a dynastic marriage to a nine year-old girl. In this case, the erect codpiece and the intent, serious, challenging gaze may very well be directed at the father, pointing out to him the inescapable difference between the eighteen-year-old Guidobaldo and the nine-year-old Giulia.

On a more personal level, Guidobaldo, at this time still an only son, may also have been pointing out to his father that the della Rovere family was dependent on the contents of Guidobaldo's codpiece, not his father's, to procure for it the male progeny indispensable to any ruling dynasty. If the painting can be dated, as the inscription on the tablecloth suggests, to the period between April 1531 and April 1532, then the duchess Eleonora was not yet pregnant with her second son. Giulio (born in April 1533, and. therefore, conceived in July 1532). Given this, then Guidobaldo`s suggestion to his father that the fortunes of the family lineage were dependent on the young man, not the old patriarch, would further help us to understand the reasons for the frayed nerves evident in the exchange of letters between father and son in late 1532. Francesco Maria. who was only 42 years old at this time. would certainly not have appreciated the implications of the suggestion made by his own son as to which of them would provide the della Rovere with additional male heirs.

In 1532 Bronzino was eager to leave the della Rovere court at Pesaro; his teacher and mentor, Pontormo, was calling him back to Florence to help with frescoes at the Medici villas. Relatively little is known of Bronzinoss one and a half year stay in Pesaro. ${ }^{14}$ Charles McCorquodale suggests that there are uncertainties present when he says:

Conclusions about the Pesaro visit must remain largely a matter of conjecture, especially in view of Vasari's brevity with regard to these years. It seems odd that Bronzino does not appear to have been commissioned to paint the Duke of Urbino, Francesco Maria I or his wife Eleonora Gonzaga. He never returned to either Pesaro or Urbino, probably on account of the della Rovere's family's success in obtaining the services of Titian almost immediately after Bronzino's departure. Guidobaldo seems to have gone out of his way to favour Titian, and the whole episode of 
Bronzino's visit appears to have [been] quickly forgotten, with the many subsequent misattributions of his Pesaro work. ${ }^{15}$

The misattributions, it must be pointed out, are Florentine rather than Urbinate. In his well-documented article, Fert Sangiorgi clearly points out that in the inventories of paintings at the palace in Urbino, the portrait of Guidobaldo II was properly identified; ${ }^{16}$ once it was transferred to Florence, however, it was misattributed to, among others, Federico Zuccari, Federico Barocci, and eventually to Pontormo, at which point it was also misidentified as the portrait of Cardinal Ippolito de' Medici with a dog, mentioned by Vasari in his life of Pontormo. ${ }^{17}$

The reasons for the "odd' fact that Bronzino never painted the ruling duke Francesco Maria, or his wife Eleonora, or for the fact that Bronzino never returned to the duchy of Urbino may lie, partly, in the della Rovere patronage of Titian, but also, I would propose, in Guidobaldo's desire to distance himself from Bronzino and the portrait of 1532 . Bronzino, on his part, having been brought to Pesaro by the erring young duke and having created, albeit on commission, the masterpiece which spoke so loudly and bluntly on delicate family matters, may have felt ill at ease in the duchy. The implications of the portrait and the climate of tension in the della Rovere household should therefore not be discounted in Bronzino's eagerness to return to Florence. In support of this, it is worth underlining that Bronzino was not moving towards a more prestigious appointment; on the contrary, instead of being court painter and portraitist to the duke (as was the case in Pesaro). Bronzino was returning to Florence to be someone else's (Pontormo`s) assistant, to help paint frescoes in the Medici country villas, a rather subserviant position in the completion of a rather private and relatively unimportant commission. ${ }^{18}$

Lastly, it is instructive to consider this portrait alongside the later one, by Titian, of Guidobaldo II with his son and heir Francesco Maria II (ca. 1552-53: private collection). ${ }^{19}$ Compared with the Bronzino portrait, the Titian portrait (fig. 3) is much more subdued in the manner in which Guidobaldo has chosen to present himself. The mastiff has disappeared entirely, and the helmet has been moved into the upper portion of the portrait and somewhat into the background to make room for the new young heir to the duchy. Francesco Maria II della Rovere. Born in 1549 of Guidobaldo's second wife, Vittoria Farnese, Francesco Maria II was destined to be not only the last of the della Rovere dukes, but also the last duke of Urbino. ${ }^{20}$ Two batons or military sceptres are propped up beside the white-plumed, blue-black helmet, and parts of the armour are visible along the left edge of the canvas. The duke has obviously chosen to continue to identify himself with military endeavours, as the inscription SRESURP on the thin banner wrapped around the batons indicates, 
30 / Renaissance and Reformation

FIGURE 3: Titian. Duke Guidobaldo II della Rovere and his son Francesco Maria II. Private collection. (Rpt with permission from Phaidon)

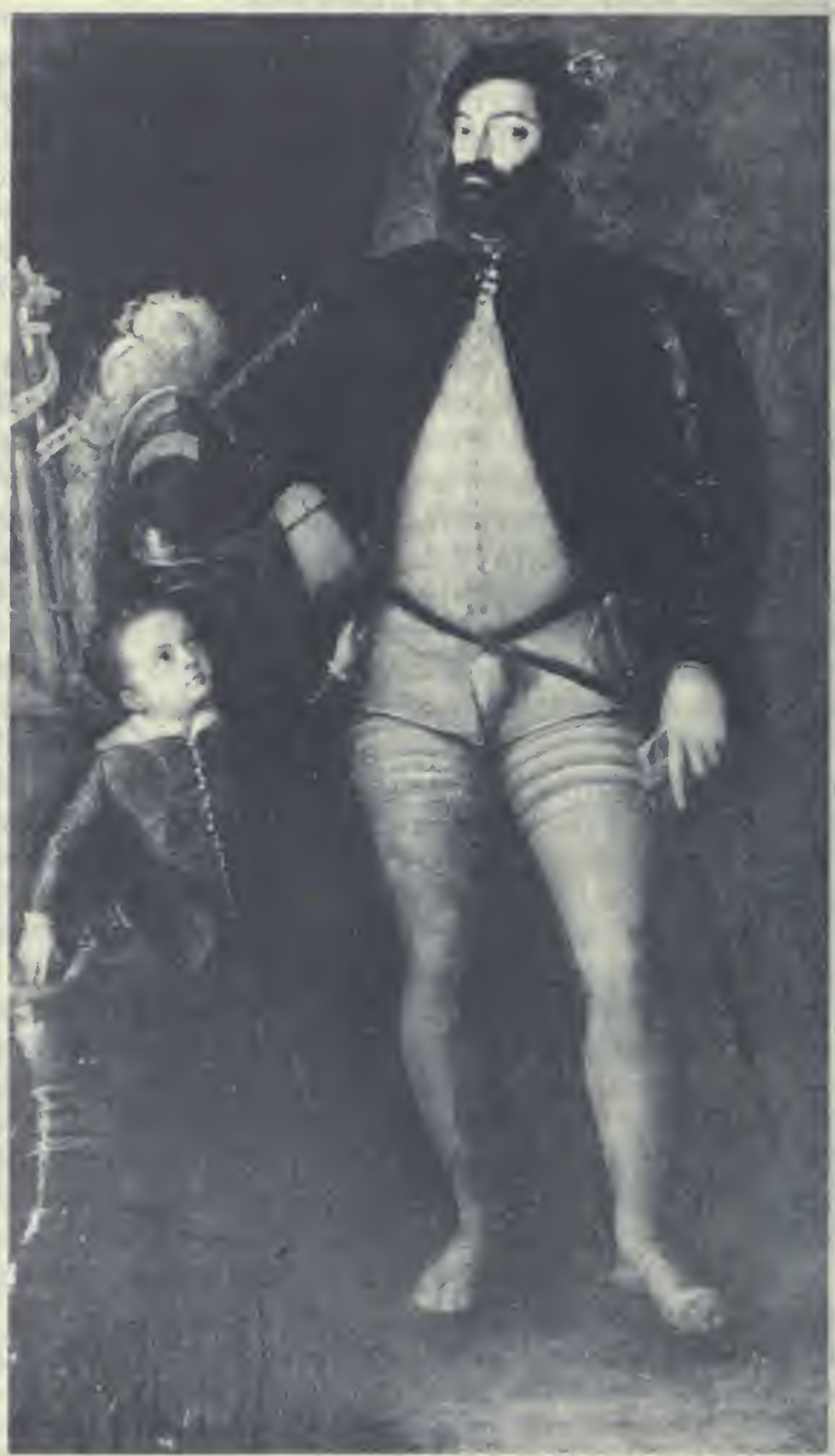


Guidobaldo was now Standardbearer of the Holy Roman Church and Prefect of the City of Rome (1553). ${ }^{21}$ The exhuberant, erect codpiece of the Bronzino portrait has been drastically reduced. Although fairly centrally located in the painting, it no longer attracts the viewer's attention; instead, it has blended with the white doublet and hose to become merely another well-integrated component of standard male attire for the period, not unlike the codpiece in Titian's well-known portrait of the emperor Charles V with hound (ca 1536, Prado). At this point, then, the attenuated presentation of power and virility on Guidobaldo's part may very well indicate that, having come to terms with both his father's dynastic desires for the della Rovere family and with his own role in that masterplan, the well-established 39-year-old Guidobaldo had no further need to display himself as brashly as he had in 1532 when, as a young man in love, he had flaunted his rebellion against the restrictions imposed upon him by his father's dynastic ambitions.

\section{University of Toronto}

Notes

1 Florence, Pitti (inv. 149). Oil on panel. $114 \times 86 \mathrm{~cm}$. Latin inscription on the edge of the table in the lower 1.h. corner: ANNUM AGEBAT DECIMUM OCTAVUM. Greek inscription on the broach on the helmet, translated by Emiliani as "Sarà certamente secondo il divisamento che ho fatto."

Selected bibl.: Karl Justi, "Die Bildnisse des Kardynals Hippolyt von Medici in Florenz," Zeitschrift für bildende Kunst, N.F. 8 (Leipzig, 1897), pp. 34-40; A.J. Rusconi, La Reale Galleria Pitti (Roma, 1937), p. 80; Fert Sangiorgi, "Sul Guidobaldo II del Bronzino," Antichità viva, 8:4 (1969), 25-27; Craig Hugh Smyth, “Bronzino Studies" (Ph.D. diss., Princeton University, 1955), pp. 130-35; Adolfo Venturi, Storia dell'arte italiana, Vol. IX(Milan, 1933), p. 70. For a bibliography of works on Bronzino's career see Craig Hugh Smyth, "The Earliest Works of Bronzino," The An Bulletin, 31 (1949), p. 184, n. 2; rpt in his "Bronzino Studies," p. 8; and Charles McCorquodale, Bronzino (London: Jupiter Books, 1981), pp. 164-65.

2 Because the inscription on the tablecloth in the portrait reads that the sitter is 18 years old ("Annum agebat decimum octavum"), the portrait must have been painted between Guidobaldo's 18th and 19th birthdays, 2 April 1531 and the same date in 1532. See Charles McCorquodale, p. 40.

3 "Il quale Bronzino, se bene era ogni giorno mandato a chiamare da Iacopo, non però si poteva a sua posta partire, però che avendo fatto nel peduccio d'una volta all'imperiale un Cupido ignudo mol to bello et i cartoni per gl'altri, ordinò il prencipe Guidobaldo, conosciuta la virtủ di quel giovane, d'essere ritratto da lui. Ma percioché voleva essere fatto con alcune arme che aspettava di Lombardia, il Bronzino fu forzato trattenersi più che non arebbe voluto con quel prencipe." Giorgio Vasari, Le vite (Novara: De Agostini, 1967), 6:173.

4 Andrea Emiliani gives the Greek transcription and translates it into Italian as "Sarà certamente secondo il divisamento che ho fatto" in his Il Bronzino (Busto Arsizio: Bramante, 1960), facing pl. 12; Edi Baccheschi translates the Greek, saying: "sull'elmo, una scritta in caratteri greci, probabilmente un motto, interpretabile come: 'Sarà certamente secondo ciò che mi sono proposto'." L'opera completa del Bronzino, Introdotta da scritti del pittore e coordinata da Edi Baccheschi (Milano: Rizzoli, 1973), p. 88. For a discussion of Greek at the court of Urbino, see Cecil H. Clough, "Cardinal Bessarion and Greek at the Court of Urbino," Manuscripta, 8 (1964), 160-71; rpt in his The Duchy of Urbino in the Renaissance (London: Variorum Reprints, 1981). 


\section{2 / Renaissance and Reformation}

5 Smyth, p. 131.

6 McCorquodale, p. 40.

7 Ibid.

8 Baldesar Castiglione, The Book of the Courtier, tr. Charles S. Singleton (Garden City. NY: Doubleday-Anchor, 1959), p. 14.

9 Castiglione, p. 14.

10 Francesco Maria, accompanied by his wife the duchess Eleonora. was away from the duchy at this time, inspecting the Venetian troops in Lombardy, the Veneto, and Friuli (Francesco Maria was Captain-General of the Venetian land forces). Guidobaldo. on the other hand, had been left in Pesaro to act as regent for his absent parents. This was the first time the eighteenyear-old youth, who had recently received a small military command and salary from Venice. had been left in charge of the state. It is not surprising. then. that the young heir to the throne may have overestimated his own self-importance and underestimated his fathers power. Dennis Dennistoun, Memoirs of the Dukes of Urbino ... 1440-1630, with notes by Edward Hutton, 3 vols. (London and New York: John Lane Company, 1909), 3:58-59.

The letters are to be found in: Arch. centr., Carte d'Urbino. cl. 4. div. G. filza 108. They are paraphrased and selections are quoted in Filippo Ugolini. Storia dei conti e duchi d'Urbino (Firenze: Grazzini, Giannini, 1859). 2:247-250. The extracts are from this work.

11 "E' mi par di comprendere che tu abbi una gran paura di diventar duca di Camerino: pensa. pensa al debito tuo prima che a tor moglie: massimamente avendo madre che ha pieno il corpo. e che ne può far dieci benissimo." Cited in Ugolini, p. 248.

12 "E quando sentirò il contrario di quel ch iocomando, farò contro di te. prima. quelloche uomo non penseria che forsi mai padre facesse a figliuolo: e contro la madre di lei [Gian Giordano Orsini was deceased]. e contro la figliuola e figliuoli. li sa rò tanto acerbo nemico. che mi rendo certo che li abbia da uscir di mente la inimicizia de lo abate [unknown episode]: e a chi se ne impaccerì, non solo perseguiterò in la roba, ma in la vita.e in nell animo ancora, se si potrà. senza un rispetto a ogni persona: e quando vedrò che non basteranno le parole. se ce useranno i fatti contro (qualsivoglia. senza una riserva al mondo: e quando farai il debito tuo. e io farò il debito mio. che sarà tutto il contrario." As cited in Ugolini. pp. 249-50.

13 Political, not personal events were the primary reason for the hurry. The death of pope Clement VII de Medici (25 September 1534) and the anticipated election of cardinal Alessandro Farnese as pope (Paul 111. on 12 Octoher 1534) precipitated the marriage. Francesco Maria. always the astute politician hut also the intrepid soldier. seems to have read very clearly both the results of the fortheoming conclave and the Farnese cardinal's dynastic plans for his natural son Pierluigi: as a result. Francesco Maria acted quickly to protect his own family's position in the area. On hearing of Clement VII's death (who also had not been in support of the della Rovere-Varano marriage). Francesco Maria sent Guidobaldo to Camerino with the express order to complete the ceremony and consummate the marriage. thus presenting the pope-to-he' with a fait ac'ompli - the installation of a della Rovere rather than a Farnese in the duchy of Camerino. See Dennistoun, pp. 66-69; also Ugolini. pp. 251-52.

14 According to Vasari (Vite. VI. 17.3 and VIII. 15). Bronzino left Florence shortly after its capitulation to the besicging imperial forces (12 August 15.30) and went to Pesaro to work for the young duke Guidobaldo.

15 Micorquodale, pp. 4()-41.

16 For a discussion of the misattributions, as well as the portrait stransfer to Florence in October 1631, see Sangiorgi. pp. 25-27.

17 "In quel |ritratto) d"Ipolito ritrasse insieme un cane molto favorito di quel signore, chiamato Rodon, e lo fece cosi proprio e naturale che pare vivissimo." Vasari, VI, 171. Karl Justi reproposed the Bronzino attribution. subsequently accepted by most scholars: see Emiliani. facing plates 11 and 12, and Sangiorgi s article.

18 Bronzino's fortunes at the Medici court did not rise until Cosimol came to power (1536); and. even then, they rose slowly. The decorations for the wedding of Cosimo I and Eleonora of Toledo (1539), for example, were supervised by Aristotile da Sangallo, who used Bronzino as 
one of his many decorators (to paint scenes on the base of Tribolo's enormous equestrian statue of Giovanni delle Bande Nere in Piazza S. Marco, for instance; Vasari, VIII, 18). Even Vasari, recalling the decorations for the wedding, undermines Bronzino's contribution with a back-handed compliment when he says that Bronzino was one of the "young painters" who worked under Tribolo's supervision in the decorations of the cortile of the palazzo Medici in via Larga (V, 474) - we must remember, however, that it was Vasari himself who replaced Bronzino as Cosimo's court painter, and therefore his comments may have been coloured by a certain amount of artistic rivalry. However, Bronzino's decorations did catch Cosimo I's attention, and land him the commission for the frescoes in Eleonora's private chapel; a rather small room $(4.90 \mathrm{~m} . \times 3.85 \mathrm{~m}$.) in Eleonora's private apartment in the Palazzo della Signoria, painted in 1540-42 with stories from the life of Moses (Vasari, VIII, 18-19; McCorquodale, pp. 66-96; Janet Cox-Rearick, "Les Dessins de Bronzino pour la chapelle d'Eleonora au Palazzo Vecchio," Revue de l'art, 14, pp. 7-22). It was only at this time and in the years following, that Bronzino finally became the official court portraitist, painting the likeness of Cosimo's illegitimate daughter Bia (ca. 1542), his cherubic little son Giovanni (1545), Cosimo himselfșeveral times - (1545-46), and Eleonora with a more serious Giovanni by her side (ca. 1546), not to mention the series of Medici ancestors all the way back to the founder of the Medici banking fortune, Giovanni di Bicci (1360-1419). It is thus evident that Bronzino's return to Florence, was not a career advancement; on the contrary, it delayed his career as court painter and portraitist by about ten years.

19 See The Paintings of Titian, complete edition by Harold E. Wethey, vol. 2, The Portraits (London: Phaidon, 1971), p. 137 and also plate 165. Also reproduced in Sangiorgi (p. 27), where it is strategically placed on a page facing the Bronzino portrait (p. 26); Sangiorgi dated the Titian to 1552-55 and located it at that time (1969) in the Matthiesen Gallery in London; two years later, in 1971, Wethey located it in a private collection.

At this point I would like to express my gratitude to Māra Ezerkalns Vilčinskas for her invaluable assistance in researching the present location of this portrait, and in obtaining permission from Phaidon to reproduce the photograph from the Wethey edition.

20 The childless Francesco Maria II della Rovere abdicated in favour of pope Urban VIII in 1626 , thus making the duchy of Urbino part of the Papal States. It was incorporated into the Kingdom of Italy in 1870.

21 Wethey, vol. 2, p. 137 and plate 165. 